Egyptian Journal of Aquatic Biology \& Fisheries

Zoology Department, Faculty of Science,

Ain Shams University, Cairo, Egypt.

ISSN $1110-6131$

Vol. 25(2): 859 - 874 (2021)

www.ejabf.journals.ekb.eg

\title{
Evaluation of the toxicity induced by industrial effluent of El-Delta for fertilizers and chemical industries company
}

\author{
Dina A. Refaay ", Doaa M. Mohammad, Sami A. Shabaan , M. I. Abdel-Hamid, \\ Mervat H. Hussein \\ Botany Department, Faculty of Science, Mansoura university, Egypt. \\ "Corresponding Author: dalirefy@mans.edu.eg
}

\begin{abstract}
ARTICLE INFO
Article History:

Online: April 30, 2021

Keywords:

Ammonia toxicity, Industrial effluent, Physico-chemical parameters, Water quality.
\end{abstract}

Received: March 27, 2021

Accepted: April 26, 2021

\section{INTRODUCTION}

ABSTRACT
Owing to their persistence and non-degradability, industrial effluents laden with high concentrations of ammonia and heavy metals are considered a major problem in densely populated developing countries. This study was displayed during the spring 2018 to winter 2019 for elucidating the pollution load that is administrated through El-Delta for fertilizers and chemical industries (EFCI) company effluent to the drainage system. Parameters included temperature, $\mathrm{pH}$, conductivity, total dissolved salts (TDS), biological oxygen demand (BOD), chemical oxygen demand (COD), dissolved oxygen (DO), total hardness, total alkalinity, chloride, $\mathrm{NO}_{2}-\mathrm{N}, \mathrm{NO}_{3}-\mathrm{N}, \mathrm{NH}_{4}-\mathrm{N}$, dissolved reactive phosphorus (DRP), total dissolved phosphorus (TDP), reactive silica and some of heavy metals $(\mathrm{Fe}, \mathrm{Zn}, \mathrm{Pb}, \mathrm{Ni}, \mathrm{Cd}$ and $\mathrm{Mn}$ ) were determined. Results demonstrated significant $(\mathrm{P} \leq 0.05)$ increments in water $\mathrm{pH}$ $(9.84 \pm 0.01), \mathrm{NH}_{4}-\mathrm{N}\left(187.76 \pm 0.14 \mathrm{mg} \mathrm{L}^{-1}\right), \mathrm{Cu}\left(0.439 \pm 0.002 \mathrm{mg} \mathrm{L}^{-1}\right)$ in the winter and TDP $\left(0.76 \mathrm{mg} \mathrm{L}^{-1}\right)$ in summer. Toxicity test was carried out using the standard test alga Pseudokirchneriella subcapitata and in parallel Chlorella vulgaris and Scenedesmus dimorphus to assess the toxicity degree of wastewater on the test microalgae growth. Wastewater was highly toxic for Pseudokirchneriella subcapitata growth with $\mathrm{EC}_{50}$ value $0.046 \%(\mathrm{v} / \mathrm{v})$, whereas the test microalgae Scenedesmus dimorphus and Chlorella vulgaris exhibited some tolerance to wastewater toxicity with $\mathrm{EC}_{50}$ values $10.323 \%$ and $18.411 \%$, respectively. Thus, these findings highlight the study area's deteriorating condition and new research opportunities that could be opened by the proposed treatment process, especially for the possible cultivation of Chlorella vulgaris and Scenedesmus dimorphus on such industrial effluent after pretreatment.

Waters are one of the main resources Earth's means for sustaining life. All creatures, regardless of size, are dependent on water. There are two primary sources of water: surface water and borehole water (Lawson, 2011). With ever-increasing population and industrialization, world is facing a global water quality crisis in surface water resources as there are small fractions of world freshwater available for direct human consumption and other living organism's uses and the other fractions are being 
contaminated enormously due to the high pollution rates by one or more of domestic effluent, agricultural activities and industrial effluent (Raschid-Sally and Jayakody, 2009).

Industrial wastewater pollution is a chive issue in developing populated countries particularly on natural water bodies that lies near to the industrial area which represent a point pollution source discharging various levels of pollutants directly into water through sewer line making such water resources unsuitable for drinking, irrigation and aquatic life. The type of industrial pollutants varies depending on the type of industry present such as fertilizer industry generates massive amounts of wastewater containing high amounts of nitrogen rich compounds, nitrate and heavy metals whereas, on discharging these nitrogenous effluents into water bodies favours eutrophication and consequently hazards drawbacks on aquatic life and human health (Osibanjo et al., 2011).

Ammonia nitrogen is a common toxicant derived from industrial effluents that may exist in two forms: ionized (ammonium, $\mathrm{NH}_{4}{ }^{+}$) and unionized (ammonia, $\mathrm{NH}_{3}$ ). Increasing $\mathrm{pH}$ favours formation of the toxic unionized form $\left(\mathrm{NH}_{3}\right)$, while the decreasing $\mathrm{pH}$ favours the ionized form $\left(\mathrm{NH}_{4}^{+}\right)$(Azov and Goldman, 1982; Randall and Tsui, 2002; Wang et al., 2019). In this regards, $\mathrm{NH}_{3}$ is documented to be more toxic than $\mathrm{NH}_{4}{ }^{+}$ as it can readily diffuse through the gill membranes of aquatic animals causing growth inhibition, immune suppression as well as high mortality (Lemarie et al., 2004; Sinha et al., 2012; Li et al., 2014). Moreover, the assimilation of ammonium nitrogen destroys the balance of carbon and nitrogen in plants besides other autotrophic organisms (Kronzucker et al., 1998).

In this concern, water quality assessment is an essential issue for estimating the degree of contamination of industrial wastewater on human, animals and plants life being based on physical properties of water, which includes temperature, total suspended solids (TSS), colour, odour and turbidity besides chemical analyses including; $\mathrm{pH}$, biochemical oxygen demand (BOD), chemical oxygen demand (COD), nutrients (nitrate and phosphorus components) and heavy metals (Sargaonkar and Deshpande, 2003) in addition to biological quality assessment (Stevenson et al., 1999). Furthermore, wastewater toxicity assessment is useful for evaluating the adverse effects of wastewater and inferring the wastewater removal efficiency indirectly. Microalgae in particular are used as pollution indices and indicators for ecological risk assessments in water bodies (Dries et al., 2014). The bioassays using different species of microalgae is more effective in the evaluation of wastewater toxicity because of their sensitivity to chemical pollution as well as their short life cycle (Li et al., 2011).

The objective of the current investigation is to analyze the industrial effluent of ElDelta for Fertilizers and Chemical Industries (EFCI) company and to assess its toxicity by the standard algal biotest using Pseudokirchneriella subcapitata, Cholrella vulgaris and Scenedesmus dimorphus. 


\section{MATERIALS AND METHODS}

\section{1- Study area}

The area of study is wastewater receiving drain receives alkaline ammonia rich industrial effluents from Eldelta for fertilizers and chemical industries (EFCI) company which produces primarily nitrogenous fertilizers. The area is located about $2 \mathrm{Km}$ north Mansoura city ( $\left.31^{\circ} 04^{\prime} 20.1^{\prime \prime} \mathrm{N}, 31^{\circ} 23^{\prime} 57.5^{\prime \prime} \mathrm{E}\right)$. The geographical location of this study area is shown in (Fig.1).

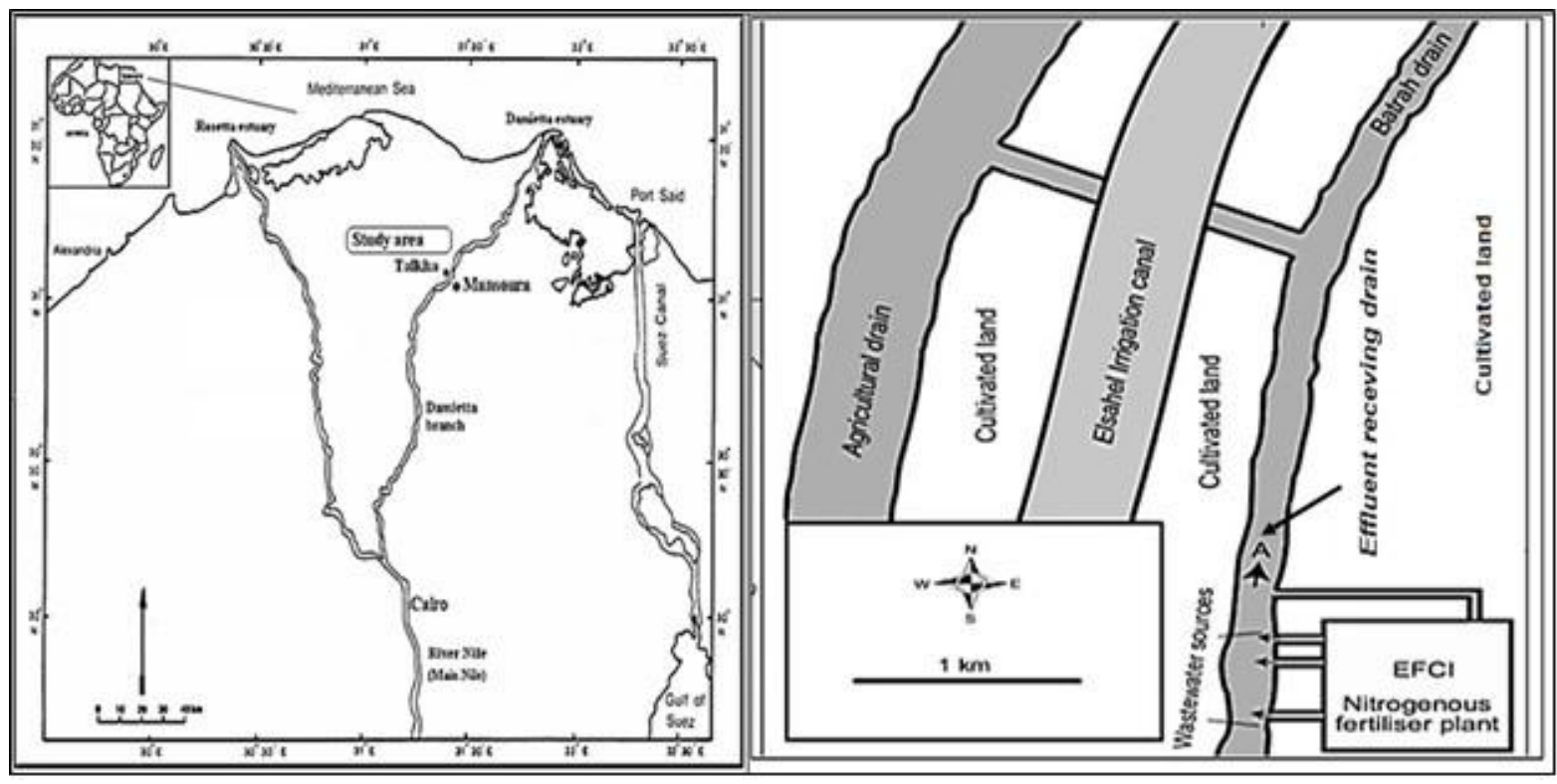

Fig. 1. A map and diagram of the study area. Arrows refers to the sampling location.

\section{2- Water sampling}

Samples of wastewater were obtained on a seasonal basis (from mid- spring 2018 to mid-winter 2019). The sample collection, handling, and processing were followed (Peltier and Weber, 1985). Upon arrival to the laboratory, four liters of each sample were filtered through $\mathrm{GF} / \mathrm{C}$ glass fiber filters. The first one liter was discarded, and the others were stored at $4{ }^{\circ} \mathrm{C}$ in dark to be used for distinctive chemical analyses.

\section{3- Physical and chemical analyses}

Physico-chemical parameters investigated included water temperature, electrical conductivity (EC), total dissolved salts (TDS), $\mathrm{pH}$, biological oxygen demands $\left(\mathrm{BOD}_{5}\right)$, reactive silica, dissolved reactive phosphorus (DRP), chloride, total hardness, ammonia $\mathrm{N}$, total alkalinity, nitrate- $\mathrm{N}$, nitrite- $\mathrm{N}$, total dissolved phosphorous (TDP), chemical oxygen demand (COD), dissolved oxygen (DO) and heavy metals ( $\mathrm{Fe}, \mathrm{Zn}, \mathrm{Cu}, \mathrm{Pb}, \mathrm{Ni}, \mathrm{Cd}$ and $\mathrm{Mn}$ ) were analyzed followed (APHA, 2005). 


\section{4- Toxicity assessment of the industrial effluent using standard algal biotest}

The algal growth inhibition assay was used to assess the toxicity of the industrial effluent followed (ISO, 2005). The standard test alga Pseudokirchneriella subcapitata and the test microalgae Cholrella vulgaris and Scenedesmus dimorphus obtained from the microalgal culture collection of the Phycology Lab, Faculty of Science, Mansoura University were used in the test to assess the degree of wastewater toxicity. A serial dilution technique was applied to prepare nine different concentrations of the test effluent, three replicates culture flasks were used for each effluent concentration with each of the test alga. $10 \mathrm{~mL}$ of the algal nutrient solution medium (AAM) (Miller et al., 1978) was added to each flask except flask (1). $1.0 \mathrm{~mL}$ of a 5 days old cultures of Pseudokirchneriella subcapitata, Chlorella vulgaris and Scenedesmus dimorphus $5 \times 10^{6}$ cells $\mathrm{L}^{-1}$ as initial algal density to give final cell density of 5000 cells $\mathrm{mL}^{-1}$ were separately inoculated into the test flasks and after that flasks were incubated for 5 days on shaker at $20{ }^{\circ} \mathrm{C}$ under continuous illumination of $\left(45 \mu \mathrm{mol} \mathrm{m}^{-2} \mathrm{~s}^{-1}\right)$. Direct cell count was used for toxicity measurements.

\subsection{EC $_{50}$ calculation}

$\mathrm{EC}_{50}$ value is the lowest effluent concentrations that inhibits algal growth by $50 \%$ as compared to the control culture. The toxicity response parameter's values were plotted as relative percent of its control (control=100\%) against the corresponding effluent concentration which allowed $\mathrm{EC}_{50}$ to be calculated using the straight-line graphical interpolation method (Walsh et al., 1987).

\section{5- Statistical analysis}

The PAST program (ver. 4.03) was used to perform statistical and correlation analyses.

\section{RESULTS}

\section{1- Physical and chemical properties of the wastewater}

Water temperature exhibited a noticeable seasonal trend with lowest value of (18.97 $\left.{ }^{\circ} \mathrm{C}\right)$ recorded in winter and the highest $\left(36.03{ }^{\circ} \mathrm{C}\right)$ in summer with mean annual value of $\left(26.01 \pm 7.29^{\circ}\right.$ C) (Table 1) whereas water temperature showed strong positive correlations $(\mathrm{r}=1.0, \mathrm{p} \leq 0.05)$ with BOD and DO (Table 3).

$\mathrm{pH}$ of water samples was almost alkaline with a mean annual value of $9.67 \pm 0.05$ while, the highest value (9.84) was recorded in winter and the lowest value (9.51) in summer (Table 1) with strong positive correlations $(r=0.9, p \leq 0.05)$ with COD (Table 3).

Electric conductivity (EC) showed minimum value of $\left(9.06 \mathrm{~ms} \mathrm{~cm}^{-1}\right)$ that was recorded in summer and the maximum value $\left(13.79 \mathrm{~ms} \mathrm{~cm}^{-1}\right)$ was documented in winter with mean annual value of $11.84 \pm 1.61 \mathrm{~ms} \mathrm{~cm}^{-1}$ (Table 1). EC exhibited positive correlation $(\mathrm{r}=0.8, \mathrm{p} \leq 0.05)$ with TDS and negative correlation $(\mathrm{r}=-1.0, \mathrm{p} \leq 0.05)$ with $\mathrm{Cd}$ (Table 3). 
Total dissolved salts (TDS) demonstrated the minimum value $\left(6.87 \mathrm{~g} \mathrm{l}^{-1}\right)$ that was recorded in summer and the maximum value $\left(8.51 \mathrm{~g} \mathrm{l}^{-1}\right)$ in winter with mean annual value of $7.62 \pm 0.75 \mathrm{~g} \mathrm{l}^{-1}$ (Table 1). TDS recorded positive correlation $(\mathrm{r}=1.0, \mathrm{p} \leq 0.05)$ with $\mathrm{Fe}$ and negative correlation $(\mathrm{r}=-0.9, \mathrm{p} \leq 0.05)$ with COD (Table 3).

Dissolved oxygen (DO) exhibited a lowest value of $\left(1.06 \mathrm{mg} \mathrm{L}^{-1}\right)$ that recorded in summer and maximum value of $\left(3.97 \mathrm{mg} \mathrm{L}^{-1}\right)$ in winter, with mean annual value of $2.75 \pm 1.22 \mathrm{mg} \mathrm{L}^{-1}$ (Table 1) demonstrating positive correlation $(\mathrm{r}=0.9, \mathrm{p} \leq 0.05)$ with $\mathrm{Zn}$ (Table 3). Biological oxygen demand (BOD) values fluctuated between $15.89 \pm 0.02$ to $19.05 \pm 0.02 \mathrm{mg} \mathrm{L}^{-1}$, with annual mean value of $\left(17.27 \pm 1.37 \mathrm{mg} \mathrm{L}^{-1}\right)$, its lowest value was recorded in summer and the highest value in winter (Table 1). It showed positive correlation ( $\mathrm{r}=1.0$ ) with DO (Table 3). Chemical oxygen demand (COD) exhibited a minimum value of $\left(16.02 \mathrm{mg} \mathrm{L}^{-1}\right)$ was recorded in summer and maximum value of (19.9 $\mathrm{mg} \mathrm{L}^{-1}$ ) in winter, with mean annual value of $17.69 \pm 1.7 \mathrm{mg} \mathrm{L}^{-1}$ (Table 1) signifying negative correlation $(\mathrm{r}=-0.7)$ with DO (Table 3).

Nitrite-N values ranged from 1.84 to $2.98 \mathrm{mg} \mathrm{L}^{-1}$ with mean annual value of $2.59 \pm 0.42 \mathrm{mg} \mathrm{L}^{-1}$, its lowest value was recorded in summer while the highest value in winter (Table 1). It was correlated positively with silica $(\mathrm{r}=1.0), \mathrm{NO}_{3}-\mathrm{N}(\mathrm{r}=0.9)$, while negatively correlated with $(\mathrm{r}=-1.0)$ with EC (Table 3). Nitrate-N concentrations ranged from 1.08 to $1.98 \mathrm{mg} \mathrm{L}^{-1}$ with mean annual value of $1.7 \pm 0.39 \mathrm{mg} \mathrm{L}^{-1}$, the lowest value was recorded in summer, while the highest value in winter (Table 1). It showed positive correlation ( $\mathrm{r}=1.0)$ with TDP and negative correlation with $\mathrm{pH}(\mathrm{r}=-1.0)$, BOD and EC ( $\mathrm{r}=$ -0.9) (Table 3). Ammonium-N accounted for the major proportion of total soluble inorganic nitrogen (TSIN). The concentrations ranged from 178.32 to $187.76 \mathrm{mg} \mathrm{L}^{-1}$, with mean annual value of $183.32 \pm 3.6 \mathrm{mg} \mathrm{L}^{-1}$, its lowest value was recorded in summer and the highest value in winter (Table 1). Ammonium-N showed strong significant $(\mathrm{p} \leq 0.05)$ positive correlations $(\mathrm{r}=1.0)$ with $\mathrm{NO}_{2}-\mathrm{N}, \mathrm{NO}_{3}-\mathrm{N}$, TDS, alkalinity $(\mathrm{r}=0.8), \mathrm{pH}$ $(\mathrm{r}=0.9)$ and negative correlation $(\mathrm{r}=-1.0, \mathrm{p} \leq 0.05)$ with DRP and EC and $(\mathrm{r}=-0.9)$ with DO and BOD (Table 3).

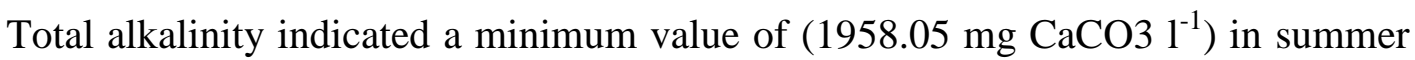
and maximum value of $\left(1999.02 \mathrm{mg} \mathrm{CaCO} \mathrm{g} \mathrm{l}^{-1}\right)$ in winter, with mean of $1978.28 \pm 22.6$ mg CaCO3 $~^{-1}$ (Table 1) with positive correlation $(\mathrm{r}=0.9)$ with $\mathrm{pH}$ and DO (Table 3).

Dissolved reactive phosphorus (DRP) exhibited a minimum value of $\left(0.28 \mathrm{mg} \mathrm{L}^{-1}\right)$ was recorded in winter and the maximum value $\left(0.39 \mathrm{mg} \mathrm{L}^{-1}\right)$ in summer, with an annual average of $0.33 \pm 0.04 \mathrm{mg} \mathrm{L}^{-1}$ (Table 1). Total Dissolved phosphorus (TDP) concentration ranged from 0.53 to $0.76 \mathrm{mg} \mathrm{L}^{-1}$. The lowest value was recorded in winter and the highest value in summer with a mean annual average of $0.65 \pm 0.08 \mathrm{mg} \mathrm{L}^{-1}$ (Table 1). DRP recorded strong significant $(\mathrm{p} \leq 0.05)$ positive correlations with $\mathrm{EC}(\mathrm{r}=1.0)$, TDP $(\mathrm{r}=0.9)$, $\mathrm{COD}(\mathrm{r}=0.8)$ and strong negative correlations with $\mathrm{pH}(\mathrm{r}=-1.0)$, TDS $(\mathrm{r}=-0.9)$ (Table 3). $\mathrm{N}: \mathrm{P}$ weight ratio is an important ecological parameter that governing nutrient limitations ( $\mathrm{P}$ and $\mathrm{N}$ ) in aquatic ecosystems. Values ranged from 157.6 to 237.9 with mean annual 
value of 195.01 \pm 9.8 . The highest ratio was recorded in winter and the lowest ratio was recorded in summer (Table 1).

Reactive silica concentration varied from 0.07 to $0.15 \mathrm{mg} \mathrm{L}^{-1}$ with mean annual value of $0.11 \pm 0.02 \mathrm{mg} \mathrm{L}^{-1}$. The lowest value was recorded in winter and the highest value in summer (Table 1) with strong significant $(\mathrm{p} \leq 0.05)$ positive correlations with DO $(\mathrm{r}=0.9)$ and negative correlations with EC $(\mathrm{r}=-1.0)$ and DRP $(\mathrm{r}=-0.9)$ (Table 3).

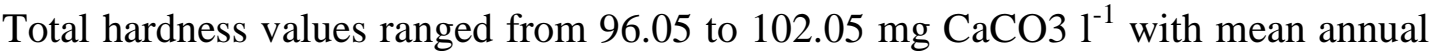
value of $99.04 \pm 1.5 \mathrm{mg} \mathrm{CaCO} 3 \mathrm{1}^{-1}$, its lowest value was recorded in summer and the highest value in winter (Table 1) with strong significant $(\mathrm{p} \leq 0.05)$ positive correlation with $\mathrm{Zn}(\mathrm{r}=0.9)$ and negative correlation with COD $(\mathrm{r}=-0.9)$ (Table 3).

Chloride minimum value $\left(3509.35 \mathrm{mg} \mathrm{L}^{-1}\right)$ was recorded in winter and the maximum value $\left(3592.07 \mathrm{mg} \mathrm{L}^{-1}\right)$ in summer with mean annual value of $3553.61 \pm 39.08$ $\mathrm{mg} \mathrm{L}^{-1}$ (Table 2). $\mathrm{Cl}$ recorded strong significant $(\mathrm{p} \leq 0.05)$ positive correlations with TDS $(\mathrm{r}=0.9)$ and negative correlations with COD $(\mathrm{r}=-1.0)$ (Table 3). Fe concentration fluctuated between 0.161 to $0.249 \mathrm{mg} \mathrm{L}^{-1}$ with mean of $0.213 \pm 0.039 \mathrm{mg} \mathrm{L}^{-1}$, its lowest value was recorded in summer and the highest in winter (Table 2). Zn concentration ranged from 0.152 to $0.250 \mathrm{mg} \mathrm{L}^{-1}$ with mean annual value of $0.204 \pm 0.041 \mathrm{mg} \mathrm{L}^{-1}$, its lowest value was recorded in summer and the highest value in winter (Table 2). The lowest value of $\mathrm{Cu}\left(0.343 \mathrm{mg} \mathrm{L}^{-1}\right)$ was recorded in summer, while the highest value $\left(0.439 \mathrm{mg} \mathrm{L}^{-1}\right)$ in winter, with mean value of $0.369 \pm 0.05 \mathrm{mg} \mathrm{L}^{-1}$ (Table 2). $\mathrm{Pb}$ concentration values ranged from 0.0188 to $0.275 \mathrm{mg} \mathrm{L}^{-1}$, with mean annual value of $0.222 \pm 0.04 \mathrm{mg} \mathrm{L}^{-1}$, its lowest value was recorded in summer and the highest value in winter (Table 2). Ni exhibited a lowest value $\left(0.153 \mathrm{mg} \mathrm{L}^{-1}\right)$ was recorded in summer and the highest value $\left(0.242 \mathrm{mg} \mathrm{L}^{-1}\right.$ ) in winter, with mean value of $0.210 \pm 0.04 \mathrm{mg} \mathrm{L}^{-1}$ (Table 2). Cd concentration values ranged from 0.131 to $0.165 \mathrm{mg} \mathrm{L}^{-1}$, with mean value of $0.147 \pm 0.02 \mathrm{mg} \mathrm{L}^{-1}$, its lowest value was recorded in winter and the highest value in summer (Table 2). Mn showed minimum value of $\left(0.225 \mathrm{mg} \mathrm{L}^{-1}\right)$ was recorded in winter and the maximum value $\left(0.322 \mathrm{mg} \mathrm{L}^{-1}\right)$ in summer, with mean value of $0.281 \pm 0.04 \mathrm{mg} \mathrm{L}^{-}$ 1 (Table 2).

Among the heavy metals, $\mathrm{Cu}$ had a strong positive correlation $(\mathrm{r}=0.8, \mathrm{p} \leq 0.05)$ with $\mathrm{Cd}$ and $\mathrm{Fe} . \mathrm{Mn}$ and $\mathrm{Ni}$ had strong positive correlation $(\mathrm{r}=1.0, \mathrm{p} \leq 0.05)$ with $\mathrm{Ni} . \mathrm{Pb}$ maintained strong positive correlation $(\mathrm{r}=1.0, \mathrm{p} \leq 0.05)$ with Fe (Table 3). 
Table 1. Summary statistics of seasonal variations of physical and chemical wastewater parameters investigated at Eldelta for fertilizers and chemical industries (EFCI) company ( Spring 2018 -Winter 2019)

\begin{tabular}{|c|c|c|c|c|c|c|c|c|c|}
\hline Parameter & Unit & $\mathbf{n}^{\mathrm{a}}$ & Spring $^{b}$ & Summer $^{b}$ & Autumn $^{\text {b }}$ & Winter $^{b}$ & $\begin{array}{c}(\text { Mean } \pm \\
\text { SD) }\end{array}$ & Maxi. $^{d}$ & $\underset{d}{\operatorname{Min}}$ \\
\hline $\mathrm{pH}$ & Unit & 4 & $9.61 \pm 0.02$ & $9.51 \pm 0.03$ & $9.74 \pm 0.02$ & $9.84 \pm 0.01$ & $9.67 \pm 0.05$ & 9.84 & 9.51 \\
\hline Water temperature & ${ }^{\circ} \mathrm{C}$ & 4 & $26.06 \pm 0.05$ & $36.03 \pm 0.06$ & $22.97 \pm 0.05$ & $18.97 \pm 0.06$ & $26.01 \pm 7.29$ & 36.03 & 18.97 \\
\hline Ammonium-N & $\mathrm{mg} \mathrm{l}^{-1}$ & 4 & $182.76 \pm 0.03$ & $\begin{array}{l}178.32 \pm \\
0.03\end{array}$ & $184.42 \pm 0.03$ & $187.76 \pm 0.14$ & $183.32 \pm 3.6$ & 187.76 & 178.32 \\
\hline Nitrite-N & $\mathrm{mg} \mathrm{l}^{-1}$ & 4 & $2.74 \pm 0.03$ & $1.84 \pm 0.02$ & $2.79 \pm 0.02$ & $2.98 \pm 0.09$ & $2.59 \pm 0.42$ & 2.98 & 1.84 \\
\hline Nitrate-N & $\mathrm{mg} \mathrm{l}^{-1}$ & 4 & $1.90 \pm 0.01$ & $1.08 \pm 0.03$ & $1.81 \pm 0.03$ & $1.98 \pm 0.03$ & $1.7 \pm 0.39$ & 1.98 & 1.08 \\
\hline Dissolved reactive phosphorus & $\mathrm{mg} \mathrm{l}^{-1}$ & 4 & $0.36 \pm 0.001$ & $\begin{array}{l}0.39 \pm \\
0.003\end{array}$ & $0.30 \pm 0.004$ & $0.28 \pm 0.009$ & $0.33 \pm 0.04$ & 0.39 & 0.28 \\
\hline Total dissolved phosphorus & $\mathrm{mgl}^{-1}$ & 4 & $0.71 \pm 0.005$ & $0.76 \pm 0.002$ & $0.61 \pm 0.003$ & $0.53 \pm 0.02$ & $0.65 \pm 0.08$ & 0.76 & 0.53 \\
\hline $\mathrm{N}: \mathrm{P}$ weight ratio & & 4 & 176.8 & 157.6 & 207.7 & 237.9 & $195.01 \pm 9.8$ & 237.9 & 157.6 \\
\hline Reactive silica & $\mathrm{mg} \mathrm{l}^{-1}$ & 4 & $0.13 \pm 0.001$ & $0.15 \pm 0.002$ & $0.09 \pm 0.002$ & $0.07 \pm 0.01$ & $0.11 \pm 0.02$ & 0.15 & 0.07 \\
\hline Total alkalinity & $\begin{array}{l}\mathrm{mg} \\
\mathrm{CaCO}_{3} \mathrm{l}^{-1}\end{array}$ & 4 & $1971.01 \pm 0.02$ & $\begin{array}{l}1958.05 \pm \\
0.03\end{array}$ & $1985.03 \pm 0.03$ & $1999.02 \pm 0.03$ & $\begin{array}{l}1978.28 \pm \\
22.6\end{array}$ & 1999.02 & $\begin{array}{l}1958.0 \\
5\end{array}$ \\
\hline Total hardness & $\begin{array}{l}\mathrm{mg} \\
\mathrm{CaCO}_{3} \mathrm{l}^{-1}\end{array}$ & 4 & $98.02 \pm 0.03$ & $96.05 \pm 0.02$ & $100.047 \pm 0.05$ & $102.05 \pm 0.05$ & $99.04 \pm 1.5$ & 102.05 & 96.05 \\
\hline Chlorides & $\mathrm{mg}^{-1}$ & 4 & $\begin{array}{l}3579.79 \pm \\
0.04\end{array}$ & $\begin{array}{l}3592.07 \pm 0.0 \\
3\end{array}$ & $3533.22 \pm 0.03$ & $3509.35 \pm 0.02$ & $\begin{array}{l}3553.61 \pm \\
39.08\end{array}$ & 3592.07 & $\begin{array}{l}3509.3 \\
5\end{array}$ \\
\hline Dissolved oxygen & $\mathrm{mg} \mathrm{l}^{-1}$ & 4 & $2.85 \pm 0.03$ & $1.06 \pm 0.02$ & $3.11 \pm 0.02$ & $3.97 \pm 0.06$ & $2.75 \pm 1.22$ & 3.97 & 1.06 \\
\hline Biological oxygen demand & $\mathrm{mgl}^{-1}$ & 4 & $16.57 \pm 0.02$ & $15.89 \pm 0.02$ & $17.55 \pm 0.03$ & $19.05 \pm 0.02$ & $\begin{array}{l}17.27 \pm \\
1.37\end{array}$ & 19.05 & 15.89 \\
\hline Chemical oxygen demand & $\mathrm{mg} \mathrm{l}^{-1}$ & 4 & $16.97 \pm 0.06$ & $16.02 \pm 0.02$ & $17.87 \pm 0.04$ & $19.9 \pm 0.09$ & $17.69 \pm 1.7$ & 19.9 & 16.02 \\
\hline $\begin{array}{l}\text { Total dissolved salts } \\
\text { Conductivity }\end{array}$ & $\mathrm{g} \mathrm{l}^{-1}$ & 4 & $7.15 \pm 0.06$ & $6.87 \pm 0.08$ & $7.93 \pm 0.06$ & $8.51 \pm 0.16$ & $7.62 \pm 0.75$ & 8.51 & 6.87 \\
\hline Conductivity & $\mathrm{ms} \mathrm{cm}^{-1}$ & 4 & $11.13 \pm 0.22$ & $10.06 \pm 0.08$ & $12.36 \pm 0.22$ & $13.79 \pm 0.26$ & $11.84 \pm 1.61$ & 13.79 & 9.06 \\
\hline
\end{tabular}

a Number of samples.

${ }^{\mathrm{b}}$ Mean of three readings \pm standard deviation.

${ }^{c}$ Annual mean \pm standard deviation .

${ }^{\mathrm{d}}$ Seasonal mean value 
Table 2. Summary statistics of seasonal variations of heavy metals investigated at Eldelta for fertilizers and chemical industries (EFCI) company during (Spring 2018 -Winter 2019).

\begin{tabular}{lccccccccc}
\hline Parameter & Unit & $\mathbf{n}^{\mathbf{a}}$ & Spring $^{\mathbf{b}}$ & Summer $^{\mathbf{b}}$ & Autumn $^{\mathbf{b}}$ & Winter $^{\mathbf{b}}$ & (Mean \pm SD) $^{\mathbf{c}}$ & Maxi. $^{\mathbf{d}}$ & Min. $^{\mathbf{d}}$ \\
\hline $\mathrm{Cu}$ & $\mathrm{mgl}^{-1}$ & 4 & $0.344 \pm$ & $0.343 \pm 0.003$ & $0.351 \pm 0.003$ & $0.439 \pm 0.002$ & $0.369 \pm 0.05$ & 0.439 & 0.343 \\
& & & 0.001 & & & & & \\
$\mathrm{Mn}$ & $\mathrm{mgl}^{-1}$ & 4 & $0.293 \pm 0.001$ & $0.322 \pm 0.003$ & $0.283 \pm 0.002$ & $0.225 \pm 0.002$ & $0.281 \pm 0.04$ & 0.322 & 0.225 \\
$\mathrm{Cd}$ & $\mathrm{mgl}^{-1}$ & 4 & $0.153 \pm 0.003$ & 0.165 & $0.138 \pm 0.002$ & $0.131 \pm 0.001$ & $0.147 \pm 0.02$ & 0.165 & 0.131 \\
& & & & \pm 0.001 & & & & 0.275 & 0.188 \\
$\mathrm{~Pb}$ & $\mathrm{mgl}^{-1}$ & 4 & $0.196 \pm 0.002$ & $0.188 \pm 0.003$ & $0.229 \pm 0.01$ & $0.275 \pm 0.02$ & $0.222 \pm 0.04$ & 0.25 \\
$\mathrm{Ni}$ & $\mathrm{mgl}^{-1}$ & 4 & $0.224 \pm 0.01$ & $0.153 \pm 0.01$ & $0.220 \pm 0.01$ & $0.242 \pm 0.02$ & $0.210 \pm 0.04$ & 0.242 & 0.153 \\
$\mathrm{Fe}$ & $\mathrm{mgl}^{-1}$ & 4 & $0.203 \pm 0.007$ & $0.161 \pm 0.01$ & $0.236 \pm 0.01$ & $0.249 \pm 0.005$ & $0.213 \pm 0.039$ & 0.249 & 0.161 \\
$\mathrm{Zn}$ & $\mathrm{mgl}^{-1}$ & 4 & $0.197 \pm 0.003$ & $0.152 \pm 0.003$ & $0.218 \pm 0.007$ & $0.250 \pm 0.002$ & $0.204 \pm 0.041$ & 0.250 & 0.152
\end{tabular}

${ }^{\text {a }}$ Number of samples.

${ }^{\mathrm{b}}$ Mean of three readings \pm standard deviation.

${ }^{c}$ Annual mean \pm standard deviation.

${ }^{\mathrm{d}}$ Seasonal mean value.

\section{2- The dose-response curves and $\mathrm{EC}_{50}$ values after toxicity assessment of ammonium-N rich industrial effluent}

The raw wastewater sample collected in winter, 2019 attained high levels of key element involved in eutrophication such $(\mathrm{N})$. It contained at the same considerable high concentration of heavy metals in particular cupper, where total-N concentration and cupper concentration was 187.76 and $0.439 \mathrm{mg} \mathrm{L}^{-1}$, respectively. 
Table 3. Pearson correlation matrix of different physico-chemical parameters and heavy metals investigated among the effluent in winter 2019. The significant correlations coefficients $(\mathrm{P} \leq 0.05)$ are only listed down.

\begin{tabular}{|c|c|c|c|c|c|c|c|c|c|c|c|c|c|c|c|c|c|c|c|c|c|c|c|c|c|}
\hline Parameter & Unit & & 1 & 2 & 3 & 4 & 5 & 6 & 7 & 8 & 9 & 10 & 11 & 12 & 13 & 14 & 15 & 16 & 17 & 18 & 19 & 20 & 21 & 22 & 23 \\
\hline $\mathrm{NH}_{4}-\mathrm{N}$ & $\mathrm{mg} \mathrm{l}^{-1}$ & 1 & 1 & & & & & & & & & & & & & & & & & & & & & & \\
\hline $\mathrm{NO}_{2}-\mathrm{N}$ & $\mathrm{mg} \mathrm{l}^{-1}$ & 2 & 1.0 & 1 & & & & & & & & & & & & & & & & & & & & & \\
\hline $\mathrm{NO}_{3}-\mathrm{N}$ & $\mathrm{mg} \mathrm{l}^{-1}$ & 3 & 1.0 & 0.9 & 1 & & & & & & & & & & & & & & & & & & & & \\
\hline Silica & $\mathrm{mg} \mathrm{l}^{-1}$ & 4 & 0.3 & 1.0 & 0.8 & 1 & & & & & & & & & & & & & & & & & & & \\
\hline DRP & $\mathrm{mg} \mathrm{l}^{-1}$ & 5 & -1.0 & -0.9 & 0.5 & -0.9 & 1 & & & & & & & & & & & & & & & & & & \\
\hline TDP & $\mathrm{mg} \mathrm{l}^{-1}$ & 6 & -5.0 & 0.9 & 1.0 & 0.8 & 0.9 & 1 & & & & & & & & & & & & & & & & & \\
\hline Alkalinity & $\mathrm{mgCaC}$ & 7 & 0.8 & -0.6 & -0.1 & -0.6 & 0.4 & -0.1 & 1 & & & & & & & & & & & & & & & & \\
\hline & $\mathrm{O}_{3} 1^{-1}$ & & & & & & & & & & & & & & & & & & & & & & & & \\
\hline Total & $\mathrm{mgCaC}$ & 8 & 0.4 & 0.6 & 0.2 & 0.7 & -0.3 & 0.2 & -1.0 & 1 & & & & & & & & & & & & & & & \\
\hline hardness & $\mathrm{O}_{3} 1^{-1}$ & & & & & & & & & & & & & & & & & & & & & & & & \\
\hline $\mathrm{Cl}$ & $\mathrm{mg} \mathrm{l}^{-1}$ & 9 & -0.7 & -0.4 & -0.8 & -0.3 & 0.7 & -0.8 & -0.5 & 0.4 & 1 & & & & & & & & & & & & & & \\
\hline $\mathrm{EC}$ & $\mathrm{ms} \mathrm{cm}_{1}^{-}$ & 10 & -1.0 & -1.0 & -0.9 & -1.0 & 1.0 & -0.8 & 0.5 & -0.6 & 0.5 & 1 & & & & & & & & & & & & & \\
\hline TDS & $\mathrm{g} \mathrm{l}^{-1}$ & 11 & 1.0 & 0.9 & 1.0 & 0.8 & -9.0 & 1.0 & -0.1 & 0.8 & 0.9 & 0.8 & 1 & & & & & & & & & & & & \\
\hline $\mathrm{pH}$ & Unit & 12 & 0.9 & -0.9 & -1 & -0.8 & -1.0 & 1.0 & 0.9 & -0.2 & 0.6 & 0.6 & 0.4 & 1 & & & & & & & & & & & \\
\hline $\mathrm{T}$ & $\mathrm{C}^{\mathrm{o}}$ & 13 & 0.3 & 0.03 & 0.5 & -0.1 & -0.4 & 0.5 & 0.8 & -0.8 & -0.9 & -0.1 & 0.5 & 0.5 & 1 & & & & & & & & & & \\
\hline BOD & $\mathrm{mg} \mathrm{l}^{-1}$ & 14 & 0.5 & 0.03 & 0.5 & -0.1 & -0.4 & 0.5 & 0.8 & -0.8 & -0.9 & -0.3 & 0.5 & -0.5 & 1.0 & 1 & & & & & & & & & \\
\hline COD & $\mathrm{mg} \mathrm{l}^{-1}$ & 15 & -0.9 & -0.5 & -0.9 & -0.5 & 0.8 & -0.9 & -0.4 & 0.3 & -1.0 & 0.6 & -0.9 & 0.9 & -0.9 & 0.4 & 1 & & & & & & & & \\
\hline DO & $\mathrm{mg} 1^{-1}$ & 16 & -0.9 & -0.9 & 0.3 & 0.9 & -0.2 & 0.3 & 0.9 & -0.9 & -0.8 & 0.1 & 0.3 & -0.3 & 1.0 & 1.0 & -0.7 & 1 & & & & & & & \\
\hline $\mathrm{Cu}$ & $\operatorname{mg~} 1^{-1}$ & 17 & 0.7 & 0.7 & 0.7 & 0.2 & 0.5 & 0.6 & 0.5 & 0.3 & 0.7 & 0.7 & 0.8 & 0.4 & 0.5 & -0.5 & -0.4 & 0.6 & 1 & & & & & & \\
\hline $\mathrm{Mn}$ & $\mathrm{mg} 1^{-1}$ & 18 & 0.6 & 0.5 & 0.3 & 0.5 & 0.4 & 0.2 & 0.7 & 0.2 & 0.5 & 0.6 & 0.7 & -0.3 & 0.2 & 0.2 & -0.3 & 0.2 & 0.5 & 1 & & & & & \\
\hline $\mathrm{Cd}$ & $\operatorname{mg~} 1^{-1}$ & 19 & 0.5 & 0.3 & -0.4 & 0.7 & 0.2 & -.05 & 0.5 & 0.2 & 0.6 & -1 & 0.4 & 0.4 & 0.1 & 0.5 & -0.6 & 0.7 & 0.8 & 0.6 & 1 & & & & \\
\hline $\mathrm{Pb}$ & $m g 1^{-1}$ & 20 & 0.4 & 0.5 & 0.5 & -0.6 & -0.2 & -0.1 & 0.7 & 0.7 & 0.7 & 0.4 & 0.5 & 0.2 & 0.5 & -0.1 & -0.2 & 0.5 & 0.6 & 0.5 & 0.3 & 1 & & & \\
\hline $\mathrm{Ni}$ & $\operatorname{mg~} 1^{-1}$ & 21 & 0.3 & -0.3 & 0.1 & -1 & -0.2 & -0.8 & 0.5 & 0.6 & 0.4 & 0.7 & 0.6 & 0.4 & 0.5 & 0.4 & -0.6 & 0.6 & 0.6 & 1 & 0.4 & 0.7 & 1 & & \\
\hline $\mathrm{Fe}$ & $m g 1^{-1}$ & 22 & 0.7 & 0.4 & 0.7 & 0.3 & 0.7 & 0.3 & 0.4 & 0.1 & 0.4 & 0.6 & 1 & 0.2 & -0.1 & -0.1 & 0.5 & 0.4 & 0.8 & 0.7 & 0.3 & 1 & 0.8 & 1 & \\
\hline $\mathrm{Zn}$ & $\mathrm{mg}^{-1}$ & 23 & 1.0 & 0.3 & -1 & -0.8 & 0.5 & -0.1 & 0.3 & 0.6 & 0.4 & 0.4 & 0.9 & -0.1 & 0.5 & 0.2 & 0.1 & 0.9 & 0.5 & 0.4 & 0.8 & 0.3 & 0.6 & 0.4 & 1 \\
\hline
\end{tabular}




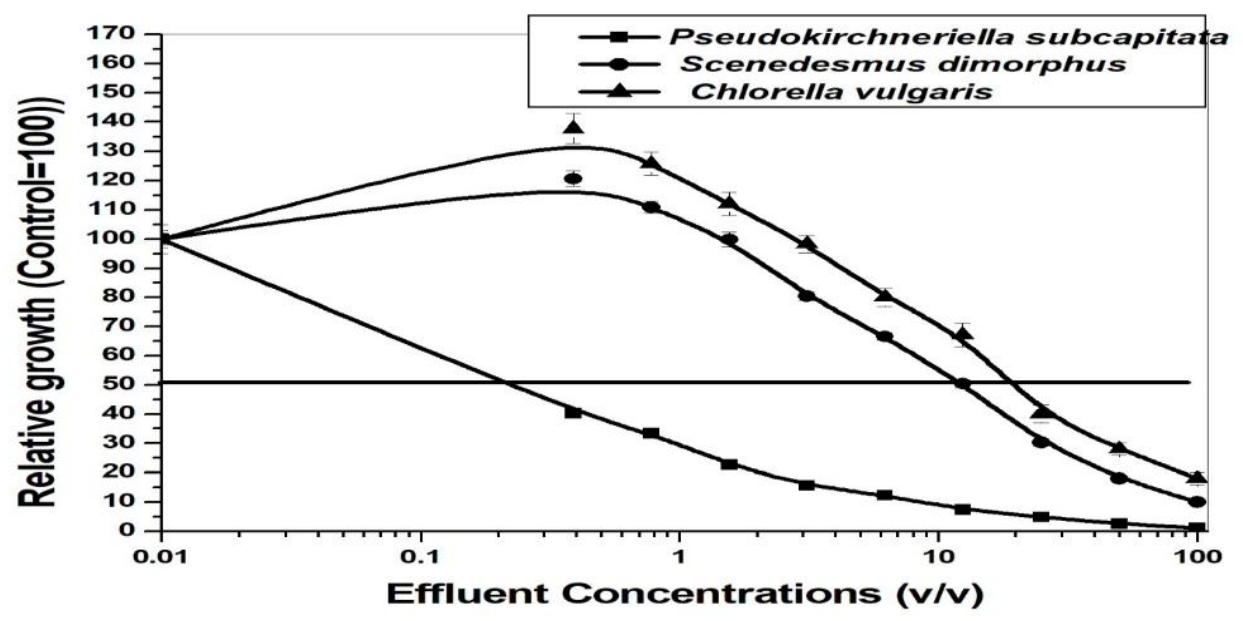

Fig. 2. Dose response curves of Pseudokirchneriella subcapitata, Scenedesmus dimorphus and Chlorella vulgaris grown in different concentrations of raw ammonium-N rich industrial effluent.

The dose - response curves (Fig.2), illustrates the growth patterns of test algae Chlorella vulgaris, Scenedesmus dimorphus and Pseudokirchneriella subcapitata in response to different concentrations (v/v) of raw effluent. The results from (Table 4, Fig. 2) indicated that wastewater was highly toxic for Pseudokirchneriella subcapitata growth with $\mathrm{EC}_{50}$ value of $0.046 \%$ whereas, marked growth stimulation was recorded with Scenedesmus dimorphus and Chlorella vulgaris at low effluent concentrations with $\mathrm{EC}_{50}$ values $10.323 \%$ and 18.411 , respectively.

Table 4. Toxicity $\left(\mathrm{EC}_{50}\right)$ of raw ammonium-N rich industrial wastewater on growth of test algae Pseudokirchneriella subcapitata, Chlorella vulgaris and Scenedemus dimorphus.

\begin{tabular}{lll}
\hline Test algae & $\mathbf{E C}_{\mathbf{5 0}} \%(\mathbf{v} / \mathbf{v})$ & Toxicity level \\
\hline Chlorella vulgaris & 18.411 & Toxic \\
Scenedesmus dimorphus & 10.323 & Toxic \\
Pseudokirchneriella subcapitata & 0.046 & Highly toxic \\
\hline
\end{tabular}

\section{DISCUSSION}

Assessment of physico-chemical properties of any aquatic ecosystem is very effective tool in evaluating the quality and status of water. Accordingly, seasonal variations of some reliable and pertinent water quality physico-chemical parameters were investigated along the study area along one year, the idea was to assess the seasonal variation of water quality during the period of study, the parameters evaluated were highly recommended as reliable and pertinent water quality measurements (APHA, 1998; WHO, 2006) . 
It is relevant to mention that the area of study is a wastewater receiving drain that receives alkaline-ammonia-rich industrial effluents from Eldelta for fertilizers and chemical industries (EFCI) company that produces mainly nitrogenous fertilizers (Fig.1). Results recoded in Tables 1,2 are seasonality dependent. The results shown significant $(\mathrm{P} \leq 0.05)$ increase in water $\mathrm{pH}$, conductivity, TDS, BOD, COD, DO, total hardness, total alkalinity, $\mathrm{NO}_{2}-\mathrm{N}, \mathrm{NO}_{3}-\mathrm{N}, \mathrm{NH}_{4}-\mathrm{N}$ and heavy metals in the winter which are in agreement with that documented by (El-Sheekh et al., 2005; Abdel-Hamid et al., 2017). It has been reported that variation in physical and chemical parameters of industrial effluent is dependent on seasonality and industrial activity that might be high in winter, besides Egypt climate which characterized by low precipitation during months of winter leads to more concentrated effluent (Banerjee et al., 2016; Bayo and López-Castellanos, 2016; Howell et al., 2016; Ebrahimi et al., 2017). Water alkalinity detected may be attributed to the high concentration of ammonium-N discharged by the industry to the effluent which reflects the high degree of the effluent deterioration. In this concern $\mathrm{pH}$ considered as one of the most powerful variables affecting water quality, solubility, and toxicity of various substances in the water. Moreover, the increase in $\mathrm{pH}$ decreases the availability of free $\mathrm{CO}_{2}$ and consequently the presence of photosynthetic organisms as algae is greatly reduced (Gupta et al., 2009).

The observed high concentrations of $\mathrm{NH}_{4}-\mathrm{N}$ investigated signified an inferior and toxic state of the area of study. Present results are in harmony with those obtained on the same study area (Abdel-Hamid $\boldsymbol{e t}$ al., 2017). It has been reported (Leta $\boldsymbol{e t}$ al., 2003) that free ammonia at high $\mathrm{pH}$ is very toxic to aquatic biota than when it's in the oxidized form and that reflects the grossly polluted conditions of this effluent. Current results (Table 1), revealed low dissolved oxygen concentration of the effluent was relatively low during the year of the study. In this regard, the insufficient dissolved oxygen in the water affecting biochemical oxidation of ammonia to nitrate and nitrite as indicated by Edokpayi $\boldsymbol{e t}$ al. (2017). This assumption accommodates with the low concentrations results of nitrate and nitrite during the study. On the other hand, the results of COD and BOD were relatively high during the year of study may be contributed to the increased oxygen demand for the decomposition of organic wastes discharged from the industry to the effluent that lead to depletion in dissolved oxygen. Phosphorus determination is essential in measurement of water quality because of being a key element in eutrophication problems. In this study the mean value of TDP of the effluent is relatively higher as TDP value of any stream should not exceed $50 \mu \mathrm{g} \mathrm{L}^{-1}$ (Higgins et al., 1988).

Science nitrogen and phosphorus are the primary limiting elements in eutrophication issues (Elser and Kimmel, 1985). It seems critical to calculate N : P weight ratio of the effluent as being an important ecological parameter governing nutrient limitations ( $\mathrm{P}$ and $\mathrm{N}$ ) in aquatic ecosystems. The results listed in Table 1 proved the effluent as highly rich in inorganic nitrogen $\left(\mathrm{NH}_{4}-\mathrm{N}\right)$ than phosphorus. 
Data of heavy metal concentrations exhibited seasonal fluctuation (Table 2) demonstrating marked increase in $\mathrm{Cu}$ concentration in winter which demonstrates high involvement of $\mathrm{Cu}$-rich materials in the industrial activities reflecting high contaminated study area. It has been widely known that the high toxicity in surface water and sediments with heavy metals is impacted by source impute, character of sediment, organic materials as well as the mineral composition of underlying rock in the region where the surface water is found (Aliyu et al., 2015).

In general, the higher values or concentrations of the physico-chemical parameters (Table 1) and heavy metals (Table 2) with special emphasis on $\mathrm{NH}_{4}-\mathrm{N}$ and signify an inferior and toxic state of the effluent discharged from Eldelta for fertilizers and chemical industries (EFCI) company specially in winter which indicated the potential toxicity of wastewater sample. In this regard, Seyoum et al. (2003) reported that the toxicity of ammonium-N to aquatic organisms is strongly $\mathrm{pH}$ dependent, and in natural aquatic habitats with high alkalinity and $\mathrm{pH}$ values above 8 most of ammonium-N form unionized ammonia with potential high toxicity to aquatic communities. Concisely, the chemical analysis alone indicated the potential toxicity of the investigated wastewater. However, it is really impossible to predict the toxicity of the wastewater from the results of chemical analysis alone. So, the use of standard algal bioassays (e.g. ISO, 2004) is highly recommended.

Accordingly, toxicity assessment using algal bioassay was carried out on wastewater samples collected in winter to assess the toxicity degree of the effluent. The use of algal bioassay started when Skulberg (1964) introduced the Selenastrum capricornutum (now Pseudokirchneriella subcapitata, ISO 1999) which has become a worldwide standard test organism in many fields of applied phycology (Abd El-Hady et al., 2005). This approach was internationally approved and being applied world-wide for toxicity assessment studies. The $\mathrm{EC}_{50}$ denotes the lowest concentration of a given toxicant inhibiting the algal growth by $50 \%$ compared to control culture (Nyholm, 1985; ISO, 1999).

In this study the toxicity test follows ISO (2005) guidelines using the ISO standard test alga, Pseudokirchneriella subcapitata. The same standard algal biotest was also employed to assess the toxicity of the investigated wastewater on growth of the test microalgae Chlorella vulgaris and Scenedesmus dimorphus based on $\mathrm{EC}_{50}$ values. The idea to include the green algae Chlorella vulgaris and Scenedesmus dimorphus based on accumulating evidences from literature (Palmer, 1980) indicating the high tolerance of both algae towards excessive pollution or eutrophication. Concisely, the selection of these microalgae to investigate their efficiency to remove ammonium- $\mathrm{N}$ was based on valid and logical reasons. Based on these facts, it has been decided to assess the toxicity of the investigated wastewater on growth of these microalgae, to define the best operational conditions for the bioremoval processes.

Present results (Table 4 and Fig. 2) the ammonia-N rich industrial effluent was highly toxic to the growth of the standard alga Pseudokirchneriella subcapitata, on the 
other side the test microalgae Chlorella vulgaris and Scenedesmus dimorphus showed some tolerance to wastewater toxicity that was firmly evidenced by marked growth stimulation at low doses of the effluent. This result highlighted the possible potential usage of both algae in practical bioremediation process of ammonium-N from the investigated wastewater. In this context, Chlorella sp. and Scenedesmus sp. are known to have a high resistance to organic matters and steady growth in a variety of wastewaters. Phosphorus, nitrogen and organic matters can all be removed simultaneously (Wang $\boldsymbol{e t}$ al., 2010; Ji et al., 2013; Abd Ellatif et al., 2020). According to the findings of Walsh et al. (1987), low $\mathrm{EC}_{50}$ value indicating high toxicity of the tested sample and vice versa. Certainly, the toxicity of a given natural sample (e.g. industrial effluents) is essentially, the sum product of additive, antagonistic and synergistic interactions among all constituents of the sample (Peltier and Weber, 1985 and Abdel-Hamid et al., 1993).

\section{CONCLUSION}

Finally, it can be concluded that the raw effluent of Eldelta for fertilizers and chemical industries (EFCI) company may have the potentiality to support an economic growth medium for Chlorella vulgaris and Scenedesmus dimorphus cultivation only after lowering ammonia levels to the probe one. In addition the findings of this study highlights the urgent need for bioremediation biotechnological strategies for industrial effluents which represent point pollution sources.

\section{AKNOWELGEMENT}

The authors are grateful to the Eldelta Fertilisers and Chemical Industries (EFCI) Administration for their support and permission to conduct this report.

\section{REFERENCES}

Abd El-Hady, D.M.; Abdel-Hamid, M.; Seliem, and El-Maali, N. (2005). Adriblastina-single stranded NA interaction with statistical analysis. Talanta 66(5): 1207-1218.

Abdel-Hamid, M.I.; Shaaban-Dessouki, S.A. and Skulberg, O.M • (1993).Water quality of the River Nile III. Toxicity assessment of industrial effluents polluting the River Nile. Environmental Toxicology and Water quality, 8: 239 - 254.

Abdel-Hamid, M.; El-Amier, Y.; Abdel-Aal, E. and El-Far, G. (2017). Water Quality Assessment of El-Salam Canal (Egypt) Based on Physico-Chemical Characteristics in Addition to Hydrophytes and their Epiphytic Algae. Int J Eco. Develop. Res 3(1): 028-043.

Abd Ellatif, S.; El-Sheekh, M. M. and Senousy, H. H. (2020). Role of microalgal ligninolytic enzymes in industrial dye decolorization. International journal of phytoremediation, 1-12. https://doi.org/10.1080/15226514.2020.1789842

Aliyu, J.Y.; Saleh, and Kabiru, S. (2015). Heavy metals pollution on surface water sources in Kaduna metropolis, Nigeria. Science World Journal 10(2): 1-5. 
APHA. (1998). Standard methods for the examination of water and wastewater. 19th Edition. American Public Health Association, American Water Works Association, Water Pollution Control Federation, Washington, DC.

APHA (American Public Health Association) (2005). Standard methods for the examination of water and wastewater (21st edn). Washington, DC: American Public Health Association, American Water Works Association, Water Pollution Control Federation.

Azov, Y. and Goldman, J.C. (1982) . Free ammonia inhibition of algal photosynthesis in intensive cultures. Applied and environmental microbiology 43(4): 735-739.

Banerjee, S.A.; Kumar, S.K.; Maiti, and Chowdhury, A. (2016). Seasonal variation in heavy metal contaminations in water and sediments of Jamshedpur stretch of Subarnarekha river, India. Environmental earth sciences 75(3): 265.

Bayo, J. and López-Castellanos, J. (2016). Principal factor and hierarchical cluster analyses for the performance assessment of an urban wastewater treatment plant in the Southeast of Spain. Chemosphere 155: 152-162.

Ebrahimi, M.E.; Gerber, L. and Rockaway, T.D. (2017). Temporal performance assessment of wastewater treatment plants by using multivariate statistical analysis. Journal of environmental management 193: 234-246.

Edokpayi, J.N.; Odiyo, J.O. and Durowoju, O.S. (2017). Impact of wastewater on surface water quality in developing countries: a case study of South Africa. Water quality: 401-416.

El-Sheekh, M.M.; El-Shouny, W.A.; Osman, M.E. and El-Gammal, E.W. (2005). Growth and heavy metals removal efficiency of Nostoc muscorum and Anabaena subcylindrica in sewage and industrial wastewater effluents. Environmental toxicology and pharmacology 19(2): 357-365.

Elser, J.J. and Kimmel, B.L. (1985). Nutrient availability for phytoplankton production in a multiple-impoundment series. Canadian Journal of Fisheries and Aquatic Sciences 42(8): 1359-1370.

Gupta, D.S.; Sunita, J. and Saharan, J. (2009). Physiochemical analysis of ground water of selected area of Kaithal city (Haryana) India. Researcher 1(2): 1-5.

Higgins, C.F.; McLaren, R.S. and Newbury, S. F. (1988). Repetitive extragenic palindromic sequences, mRNA stability and gene expression: evolution by gene conversion?-a review. Gene 72(1-2): 3-14.

Howell, C.P.; Myburgh, E.; Lategan, and Hoffman, J. (2016). Seasonal variation in composition of winery wastewater in the breede River Valley with respect to classical water quality parameters. South African Journal of Enology and Viticulture 37(1): 31-38.

ISO, H.; Stampfer, M.J.; Manson, J. E.; Rexrode, K.; Hennekens, C.H.; Colditz, G.A.; Speizer, F. E. and Willett, W.C. (1999). Prospective study of calcium, potassium, and magnesium intake and risk of stroke in women. Stroke 30(9): 17721779.

ISO/Cd 8692 (2004): Freshwater of algal growth inhibition test with unicellular green algae. International Standards Organization for Standardization (ISO) TC/SC:TC 147/SC 5. Geneva, Switzerland.

ISO (International Organization for Standardization). (2005). Water quality freshwater algal growth inhibition test with unicellular green algae. Geneva: ISO.

Kronzucker, H.; Schjoerring, J.; Erner, Y.; Kirk, G.; Siddiqi, M. and Glass, A. (1998). Dynamic interactions between root $\mathrm{NH}_{4}^{+}$influx and long-distance $\mathrm{N}$ 
translocation in rice [Oryza sativa]: Insights into feedback processes. Plant and Cell Physiology (Japan).

Lawson, E. (2011). Physico-chemical parameters and heavy metal contents of water from the mangrove swamps of Lagos Lagoon, Lagos, Nigeria. Advances in biological research 5(1): 8-21.

Lemarie, G.; Dosdat, A.; Covès, D.; Dutto, G.; Gasset, E. and Person-Le Ruyet, J. (2004) . Effect of chronic ammonia exposure on growth of European seabass (Dicentrarchus labrax) juveniles. Aquaculture 229(1-4): 479-491.

Leta, S.; Assefa, F. and Dalhammar, G. (2003). Characterization of tannery wastewater and assessment of downstream pollution profiles along Modjo River in Ethiopia. Ethiopian Journal of Biological Sciences 2(2): 157-168.

Li Y, Chen Y, Chen P, et al. (2011). Characterization of a microalga Chlorella sp. well adapted to highly concentrated municipal wastewater for nutrient removal and biodiesel production. Bioresour. Technol.102:5138-5144.

Li, M.; Yu, N.; Qin, J.G.; Li, E.; Du, Z. and Chen, L. (2014). Effects of ammonia stress, dietary linseed oil and Edwardsiella ictaluri challenge on juvenile darkbarbel catfish Pelteobagrus vachelli. Fish \& shellfish immunology 38(1): 158165.

Miller, W.E., Greene, J.C., Shiroyama, T. (1978). The Selenastrum capricornutum Printz algal assay bottle test: Experimental design, application, and data interpretation protocol, Environmental Protection Agency, Office of Research and Development .OR.

Nyholm, N. (1985). Response variable in algal growth inhibition tests-biomass or growth rate? Water Research 19(3): 273-279.

Osibanjo, O.; Daso, A.P. and Gbadebo, A.M. (2011). The impact of industries on surface water quality of River Ona and River Alaro in Oluyole Industrial Estate, Ibadan, Nigeria. African Journal of Biotechnology 10(4): 696-702.

Palmer, C. M. (1980): Algae and water pollution. - Castle House Publications Ltd: 123 p.

Peltier, W.H. and Weber, C.I. (1985) . Methods for measuring the acute toxicity of effluents to freshwater and marine organisms.3 rd ed. United States Environmental Protection Agency, Cincinnati, OH. EPA/600/4-85/013.

Randall, D.J. and Tsui, T. (2002). Ammonia toxicity in fish. Marine pollution bulletin 45(1-12): 17-23.

Raschid-Sally, L. and Jayakody, P. (2009). Drivers and characteristics of wastewater agriculture in developing countries: Results from a global assessment, IWMI.

Sargaonkar, A. and Deshpande, V. (2003). Development of an overall index of pollution for surface water based on a general classification scheme in Indian context. Environmental monitoring and assessment 89(1): 43-67.

Seyoum, L.; Fassil, A.; Dalhammer, G. (2003). Characterization of tannery wastewater and assessment of downstream pollution profiles along Modjo River in Ethiopia. Ethiop J Bio Sci. 2:157-168.

Sinha, A.K.; Liew, H.J.; Diricx, M.; Blust, R. and De. Boeck, G. (2012). The interactive effects of ammonia exposure, nutritional status and exercise on metabolic and physiological responses in gold fish (Carassius auratus L.). Aquatic Toxicology 109: 33-46. 
Stevenson, R.J.; Pan, Y. and Van Dam, H. (1999). Assessing environmental conditions in rivers and streams with diatoms. The diatoms: applications for the environmental and earth sciences 1(4).

Skulberg, O. M. (1964). Algal problems related to the eutrophication of European water supplies, and a bio-assay method to assess fertilizing influences of pollution on inland waters. In Algae and man . Springer, Boston, MA. pp. 262-299.

Walsh, G.; Deans, C. and McLaughlin, L. (1987). Comparison of four methods for calculating the EC50 from algal population growth. Environ. Toxicol. Chem 6: 767-770.

Wang, J.; Zhou, W.; Chen, H.; Zhan, He. C. and Wang, Q. (2019). Ammonium nitrogen tolerant Chlorella strain screening and its damaging effects on photosynthesis. Frontiers in microbiology 9: 3250.

WHO. (2006). Water for Pharmaceutical Uses. In: Quality Assurance of Pharmaceuticals: A Compendium of Guidelines and Related Materials. 2nd Updated edn. Geneva: World Health Organization; 2:170-171.

Wang, L.; Min, M.; Li. Y.; et al. (2010). Cultivation of green algae Chlorella sp. in different wastewaters from municipal wastewater treatment plant. Appl. Biochem. Biotechnol. 162:1174-1186.

Ji. M.; Kim, H.; Sapireddy, V.R.; et al. (2013). Simultaneous nutrient removal and lipid production from pretreated piggery wastewater by Chlorella vulgaris YSW04. Appl. Microbiol. Biotechnol. 97:2701-2710. 